\title{
Assessment of Pollutants from Diffuse Pollution through the Correlation between Rainfall and Runoff Characteristics Using EMC and First Flush Analysis
}

\author{
Maria Elisa Leite Costa *(D), Daniela Junqueira Carvalho (D) and Sergio Koide
}

check for

updates

Citation: Costa, M.E.L.; Carvalho, D.J.; Koide, S. Assessment of Pollutants from Diffuse Pollution through the Correlation between Rainfall and Runoff Characteristics Using EMC and First Flush Analysis. Water 2021, 13, 2552. https:// doi.org/10.3390/w13182552

Academic Editors: Richard C. Smardon and Francesco De Paola

Received: 24 July 2021

Accepted: 10 September 2021

Published: 17 September 2021

Publisher's Note: MDPI stays neutral with regard to jurisdictional claims in published maps and institutional affiliations.

Copyright: (c) 2021 by the authors. Licensee MDPI, Basel, Switzerland. This article is an open access article distributed under the terms and conditions of the Creative Commons Attribution (CC BY) license (https:/ / creativecommons.org/licenses/by/ $4.0 /)$.
Civil and Environmental Engineering Department, University of Brasilia, Federal District, Brasília 70910-900, Brazil; d.junqueirac@gmail.com (D.J.C.); skoide@unb.br (S.K.)

* Correspondence: mariaelisaleitecosta@hotmail.com

\begin{abstract}
Urban stormwater runoff is an important source of pollution in receiving water bodies, mainly in cities in development. However, strategies to deal with the impacts caused by the runoff discharges, such as implementing a sustainable urban drainage system (SUDS) with optimized management, need information usually obtained through monitoring studies. Brasília is a city that has one of the highest urban growth rates in Brazil, with significant impacts on urban water resources, including diffuse pollution, generated by new unregulated urban developments that initially start being built with precarious sanitation infrastructure. The Vicente Pires (VP) watershed is highly urbanized and comprises two areas that have been intensively occupied more recently, at a fast pace, and do not have yet basic sanitation systems fully implemented. Stormwater quality at the outlet of the VP watershed was analyzed by monitoring the rainfall, runoff flows, and pollutant concentration. Event Mean Concentration (EMC) and first-flush (FF) phenomenon were calculated, and hydrologic characteristics were compared for different events through correlation analysis. During dry periods the flow varied between 0.5 and $1.29 \mathrm{~m}^{3} / \mathrm{s}$, while in flood periods the maximum value was $72.17 \mathrm{~m}^{3} / \mathrm{s}$, forming floods with great volume. Nitrate during dry periods stands out with its high concentration; the maximum was $1.49 \mathrm{mg} / \mathrm{L}$, while the maximum concentration during the flood events was $0.43 \mathrm{mg} / \mathrm{L}$, probably due to dilution. Ammonia results showed very low values, probably because nitrification is occurring up to the collection point. The EMC values of solids in flood events were higher and can be attributed to river bed scour along the VP watershed. The EMC SS values for the VP watershed are also similar to areas in the initial stages of building development. The EMC values in the dry season indicate strong correlations between some water quality parameters such as $\mathrm{NH}^{+3}-\mathrm{N}$ and $\mathrm{SS}$, TS and $\mathrm{NO}_{-3}-\mathrm{N} ; \mathrm{NO}_{-3}-\mathrm{N}$, and COD. These correlations indicate that these pollutants are probably being generated by the same source, probably sewage discharges. During flood events, the correlation between pollutant loads and peak flow can be associated with the scouring during surface washing off, because greater concentrations of solids and organic matter occur in events with greater flow rates. For the first $30 \%$ of the initial runoff volume, about $29 \%$ of $\mathrm{SS}, 38 \%$ of $\mathrm{NH}^{+3}-\mathrm{N}$, and $35 \%$ of reactive $\mathrm{P}$ were carried during flood events. It was verified that large values of maximum or mean rainfall intensity are related to the occurrence of First Flush (FF) for most pollutants. Antecedent dry days (ADD) did not influence build-up processes in this watershed; however, they are related to FF occurrence. Data indicate that the sewage and stormwater collection networks were being installed caused a high impact on observed water quality, with high concentrations of solids during flood events. On the other hand, the wastewater collection after the sewer network installation led to a decrease in COD concentrations over time. For sustainable management of diffuse pollution, the adoption of distributed SUDS to enhance runoff volume reduction is a recommended solution for the case.
\end{abstract}

Keywords: urbanization; water quality; stormwater 


\section{Introduction}

Urbanization is a global phenomenon that can impart significant changes in hydrologic [1-3] and water quality systems [3-7]. Urban growth affects directly drainage processes due to vegetation removal and replacement of pervious areas by impervious surfaces which increment flows and pollutant loads that are washed downslope during storms, causing the increase of diffuse pollution loads and floods, inducing water quality deterioration [8-16]. Urban stormwaters are recognized as a source of diffuse pollution that carry a wide range of pollutants, including particulates and dissolved substances, accumulated due to land use $[17,18]$. In Brazil, the sewerage and storm drainage systems are separated and it is expected that stormwater presents very distinct quality and quantity characteristics from domestic sewage [1].

Strategies to deal with stormwater are needed to construct drainage systems, in order to ensure their functionality to guarantee flood control, public health, and economic sustainability $[1,19]$ nowadays, using sustainable urban drainage systems [20].

Information on stormwater characteristics may be achieved through monitoring studies $[5,7,9,12]$. Usually, pollutant loads are often underestimated [21] due to difficulties in monitoring, mainly during flood events [22]. The pollutant loads are aggravated by deficient individual septic systems usually adopted prior to implementation of sewage collection systems and by deficient solid waste collection services.

Runoff characteristics of each event monitored provide information to support the implementation of compensatory techniques for urban drainage that may reduce this type of pollution [23]. In addition, stormwater runoff pollution, primarily in the first minutes after the start of a rainfall event, was comparable to or greater than sewage pollution (evaluated by monitoring the VP River water quality during the dry periods) [24], which is in accordance to the first flush concept in which the first part of a rainfall event carries the major part of the pollutant load [23], which indicating how SUDs should be designed and implemented, so FF can be used to locate and size SUDs for optimal efficiency.

Brasília, Brazil's capital, is a city that is experiencing large urban growth, with a population increase of more than 4.8\% in the 2015-2018 period [25]. Therefore, Administrative Regions (ARs) such as Vicente Pires and Arniqueiras, which were considered rural areas in the mid-1990s, became irregular urban settlements that are presently being established as legal urban areas.

The Vicente Pires (VP) River runs between both ARs cited and has become an important urban watershed which discharges into the Riacho Fundo River, a major tributary of the Paranoá Lake. In the 1970s and 1980s, the lake was eutrophicated and extensive works were carried out to improve the sewage collection and to treat wastewater to a tertiary level. By 1998, the lake recovered to a good condition, but over the last decade the water quality has been worsening again. This lake's water has been used for domestic water supply since 2018, when Brasilia suffered a huge water supply crisis, including the implementation of water supply restrictions [26]. The environmental sustainability of the lake is significantly affected by the VP River nutrient loads and sediments produced by the urban area and discharged in this water body, which has suffered riverbed silting [27-29]. In spite of that, official water quality monitoring programs set up only conduct monthly water sampling, with no event-based monitoring.

The aims of this research were as follows:

(1) to compare the Vicente Pires River water quality in flood events using the event mean concentration $(E M C)$ and also by the first flush phenomenon, estimated based on multiple monitoring datasets.

(2) to correlate the pollutant load with runoff and rainfall characteristics.

(3) to discuss the possible sources of pollutants. 


\section{Materials and Methods}

\subsection{Study Area-Watershed Characteristics}

The study area is an urban watershed in the city of Brasilia, Brazil. The city is located in the Federal District (DF), which is the smallest of Brazil's 27 federation units, at approximately $5800 \mathrm{~km}^{2}$. Brasília is located in the region called the Brazilian Central Plateau, in the Cerrado biome, where the natural vegetation includes different types of vegetation, mainly of savannah type [30]. In the Federal District, the predominant soils are Red-Dark and Yellow Red Latosols, well-drained with moderate infiltration capacity and high porosity, favoring groundwater recharge, and Cambisols, being less permeable [31,32]. However, urban soils usually are altered by urbanization activities. According to the Köppen classification, the regional climate is the Savannah Climate (Aw), with a dry season during May-September and a rainy season during summer (October-April), with annual average precipitation of $1500 \mathrm{~mm}$ [33].

Because it is situated on a high plateau, the Federal District is considered a headwater region. Three major water basins in Brazil have origins within the DF. One of the Federal District's most important water bodies is the Paranoá Lake.

The study area is the Vicente Pires Watershed, which is inserted in the Paranoa Lake Watershed and has $90 \mathrm{~km}^{2}$ (Figure 1) and a population of about 350,000 people [25]. The topography is predominantly softly undulated, with the terrain being steeper near the springs of the watercourses, which are located in a plateau border region [34]. Elevations vary from $1007 \mathrm{~m}$ to $1250 \mathrm{~m}$ and the average slope is $7.3 \%$. Land uses in the watershed area are mostly urban. According to the city's Land Use Master Plan, just a small portion of the area (approximately 14\%) is designated as a rural zone, and the urban zones, consolidated and in expansion, occupy the other part [35]. In terms of land cover, $52.2 \%$ of the area is occupied by buildings and roads, $37.5 \%$ by vegetation, $8 \%$ by exposed soil, and $2 \%$ by agriculture. The Vicente Pires River is the main water body and discharges into the Riacho Fundo River, comprehending the more urbanized and densely populated affluent of the Paranoá Lake [36-38].

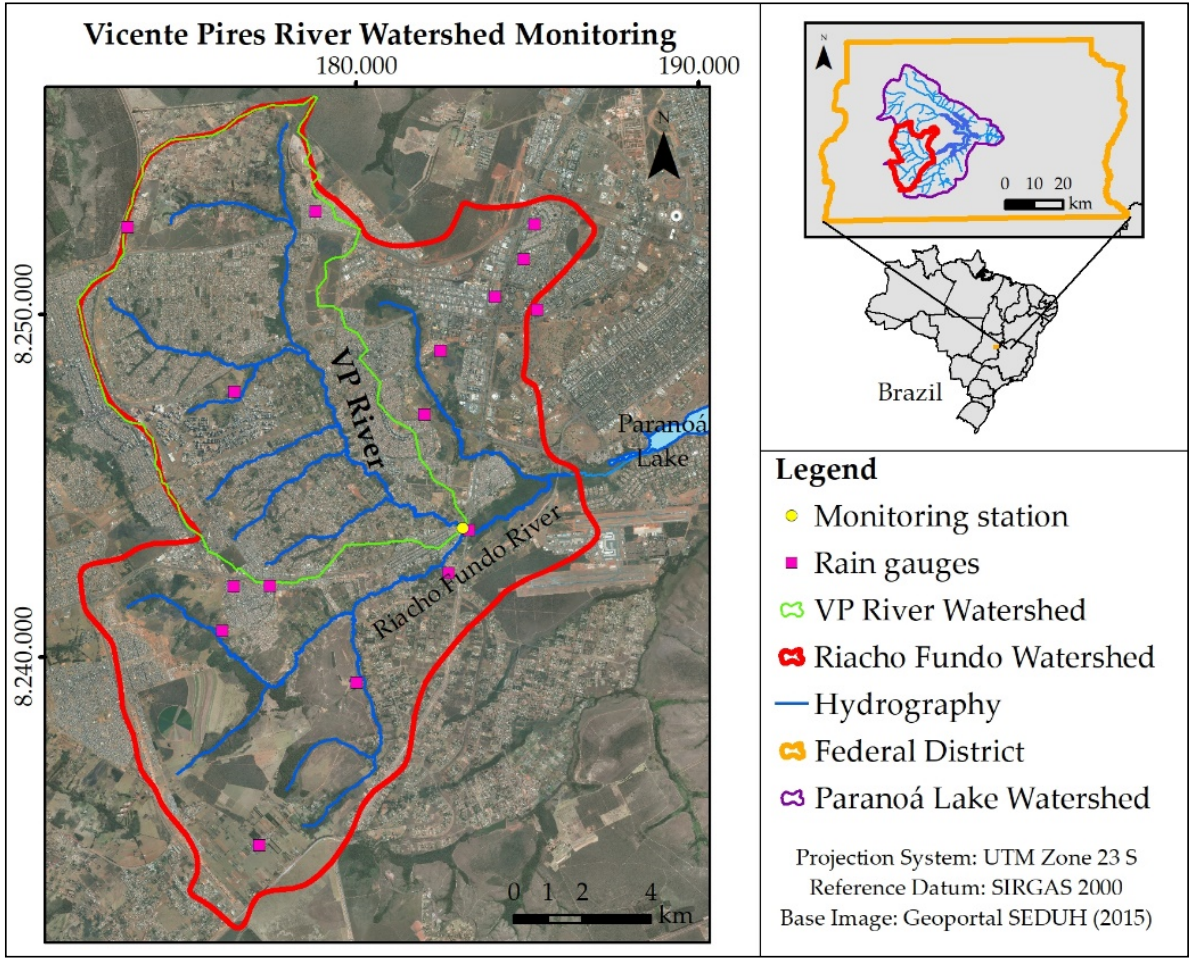

Figure 1. Location of the study area: Vicente Pires Watershed in the Federal District, Brazil. 
Brasília is known as a planned city; however, the plan comprises only part of the territory and several originally unplanned occupations occurred around it, causing many problems. Additionally, many allotments were developed in farmland areas, and in the VP watershed the rural area settlements, called Vicente Pires and Arniqueiras, were occupied by irregular urbanized areas without sanitation infrastructures, such as water supply, sewage collection, and urban drainage networks. Consequently, flood events are quite common. After many years of vindication, land regularization and construction of such infrastructure are underway.

The Federal District has legal instruments for stormwater and water resource management, including municipal plans specific to these topics. The sewer rate is based on water usage and is charged in the water bill, but there are no stormwater management taxes yet. Local agencies are conducting studies for the establishment of these taxes in the DF.

In the process of legalization of the urban occupation in the VP area, the urban drainage system under construction will include, in addition to the drainage network, the construction of 22 detention ponds to improve the sustainability of the receiving water bodies. The Arniqueiras area also does not have the sanitary infrastructure, but it is still under land regularization; therefore, there is no prediction about the beginning of stormwater management infrastructure implementation.

\subsection{Field Data Acquisition System and Water Sample Analyses}

Eleven events were monitored in terms of rainfall, flow, and water quality; six of them occurred during the rainy season and five during the dry season. The river stage was monitored using a pressure transducer level logger (model WL6, GlobalWater-Yellow Springs, OH, USA) and water sampling was carried out using an autosampler (ISCO 6712, Teledyne-Thousand Oaks, CA, USA). Both pieces of equipment were installed at the outlet of the VP watershed from 2018 to 2020. Flow rates were measured using a river discharge measurement system (River Surveyor M9, Sontek-San Diego, CA, USA). In the rainy season, samples were collected during the flood events with a $10 \mathrm{~min}$ time step, while in the dry season the sampling was carried out with $1 \mathrm{~h}$ intervals for a $24 \mathrm{~h}$ period. Rainfall intensity was monitored by four rain gauges in the study area with a 5 min time step.

Using a rating curve, flow rates and runoff volumes were estimated for evaluation of the diffuse pollution loads generated by the build-up and wash-off processes on the VP watershed. The runoff volume was accounted for a period of up to $4 \mathrm{~h}$ during each rainfall event while the water sampling was occurring. During the dry season, it was accounted for over a period of $24 \mathrm{~h}$. The runoff coefficient was calculated by dividing the runoff volume at the outlet (estimated by hydrograph separation) by the rainfall volume over the area (Thiessen method).

Water samples were analyzed in the Laboratory of Environmental Sanitation of the University of Brasilia for chemical oxygen demand (COD) as an indirect measure of organic matter content, nutrients (nitrogen and phosphorus in the forms of nitrite $\left(\mathrm{NO}_{-2}-\mathrm{N}\right)$, nitrate $\left(\mathrm{NO}_{-3}-\mathrm{N}\right)$, ammonia $\left(\mathrm{NH}_{3}-\mathrm{N}\right)$, total phosphorus (TP) and reactive phosphorus (RP)), and sediments (total solids (TS), suspended solids (SS) and dissolved solids (DS)). Analyses were carried out according to the Standard Methods for the Examination of Water and Wastewater [39]. Due to the large number of samples collected per event and the sampling frequency, automated methods were selected when available. Table 1 presents the applied methods and their technical specifications, as well as the reference methods from Standard Methods (SM) that correspond to them 
Table 1. Methods, equipment, and ranges for the analysis of water quality.

\begin{tabular}{|c|c|c|c|c|}
\hline Parameter & Method & SM Reference Method & Equipment Used & Detection Range \\
\hline COD & Reactor digestion & $5220 \mathrm{D}$ & $\begin{array}{l}\text { Spectrophotometer HACH DR } 2010 \\
\text { and Digestion reactor }\end{array}$ & 0-150 mg COD/L \\
\hline $\mathrm{NO}_{-2}-\mathrm{N}$ & Diazotization & $4500-\mathrm{NO} 2 \mathrm{~B}$ & Spectrophotometer HACH DR 4000 & $0-0.3 \mathrm{mg} \mathrm{NO}-2-\mathrm{N} / \mathrm{L}$ \\
\hline $\mathrm{NO}_{-3}-\mathrm{N}$ & Cadmium Reduction & - & Spectrophotometer HACH DR 4000 & $0-5 \mathrm{mg} \mathrm{NO}-3-\mathrm{N} / \mathrm{L}$ \\
\hline $\mathrm{NH}_{3}-\mathrm{N}$ & Nesslerization & 4500-NH3 C (1995) & Spectrophotometer HACH DR 4000 & $0-2.5 \mathrm{mg} \mathrm{NH}{ }_{3}-\mathrm{N} / \mathrm{L}$ \\
\hline $\mathrm{TP}$ & $\begin{array}{l}\text { Ascorbic acid with acid } \\
\text { persulfate digestion }\end{array}$ & 4500-P F-H & $\begin{array}{l}\text { Spectrophotometer HACH DR } 4000 \\
\text { and Digestion reactor }\end{array}$ & $\begin{array}{l}0-3.5 \mathrm{mg} \mathrm{PO}_{4}{ }^{3-} / \mathrm{L} \\
0-1.1 \mathrm{mg} \mathrm{P} / \mathrm{L}\end{array}$ \\
\hline $\mathrm{RP}$ & Ascorbic acid & 4500-P F-G & Spectrophotometer HACH DR 4000 & $0-2.5 \mathrm{mg} \mathrm{PO}_{4}^{3-} / \mathrm{L}$ \\
\hline TS & Gravimetric & $2540 \mathrm{~B}$ & $\begin{array}{l}\text { Analytical balance } \\
\text { Adventurer-OHAUS }\end{array}$ & $0-210 \mathrm{~g} / \mathrm{L}$ \\
\hline SS & Gravimetric & $2540 \mathrm{D}$ & $\begin{array}{l}\text { Analytical balance } \\
\text { Adventurer-OHAUS }\end{array}$ & $0-210 \mathrm{~g} / \mathrm{L}$ \\
\hline DS & Differential & - & - & - \\
\hline
\end{tabular}

\subsection{Water Quality Assessment Modelling}

The EMC — event mean concentration-for each parameter was calculated according to Equation (1) to compare the monitoring results. EMC is measured as the ratio of total pollutant mass and total runoff flow used to quantify a single event through composed sampling. It is a trustable parameter and allows easier comparison between events and different locations [40-43].

$$
E M C=\frac{\sum_{i}^{n}(Q i \cdot C i) \cdot \Delta t}{\sum_{i}^{n} Q i \cdot \Delta t}
$$

With:

$E M C=$ Event Mean Concentration $(\mathrm{mg} / \mathrm{L})$.

$Q=$ flow rate $\left(\mathrm{m}^{3} / \mathrm{s}\right)$.

$\mathrm{C}=$ pollutant concentration $(\mathrm{mg} / \mathrm{L})$.

$\Delta t=$ time intervals.

The $E M C$ is appropriate for evaluating the effects of runoff on receiving water bodies because it is considered an index of the polluting potential of the event [16]. The EMC calculation was applied for all parameters and monitored events to make the investigation clearer and to compare the data between events.

In diffuse pollution, due to pollutant accumulation and washing directly related to rainfall, there can be an increase in pollutant load in the first portion of the flow, known as "first flush" [44-46]. To identify this phenomenon, the dimensionless curve M(V) that indicates the disproportionality of concentrations or mass during the first portions of surface flow volume $[47,48]$ is used, which were determined for the monitored events in VP River, calculated with Equation (2).

$$
\frac{\sum_{i=1}^{j} C_{i} Q_{i} \Delta t_{i}}{\sum_{i=1}^{N} C_{i} Q_{i} \Delta t_{i}}=f\left(\frac{\sum_{i=1}^{j} Q_{i} \Delta t_{i}}{\sum_{i=1}^{N} Q_{i} \Delta t_{i}}\right)=f\left(\frac{\sum_{i=1}^{j} V_{i}}{\sum_{i=1}^{N} V_{i}}\right)
$$

where $C$ is the concentration of pollutants in the sample, $Q$ is the flow rate through the cross-section of the river, $N$ is the total number of samples, and $V$ is the volume discharged during the time interval $\Delta t i$. This way, on the $X$-axis is the accumulated fraction of water volume and on the $Y$-axis is the accumulated fraction of pollutant load carried by the accumulated volume.

The numerical coefficient " $b$ " of the curves (Equations (3) and (4)), was also calculated using simple linear regression [49]. This value expresses the length between the curve $M(V)$ and the $45^{\circ}$ line (bisector). If it is equal to one, pollutant carriage is uniform. Values lower than one indicate the occurrence of the first flush. The lowest the value of $b$ is, the greater is the value and, therefore, the pollutant load carried in the first volumes.

$$
F(X)=X^{b}
$$




$$
F(X)=X^{b}\langle=\rangle \ln (F(X))=b \cdot \ln (X)
$$

where $X$ is the accumulated volume and $F(X)$ is the accumulated load; $X \in[0,1], F(0)=0$ and $F(1)=1$. It is usually considered that the experimental adjustment between $\mathrm{M}(\mathrm{V})$ and $F(X)$ is satisfactory, with correlations of $\mathrm{R}^{2}>0.9$.

\subsection{Data Analysis}

Multivariate analyses, such as correlation, were performed to analyze the data collected, using two pieces of software: PAST 3.26 and ADDIn XLSTAT in Excel-Microsoft 365. All the analyses were performed for two separated periods: dry and flood. The correlation evaluation numerically shows the linear relationship between variables through the Pearson's coefficient ( $r$ ), for which a value of $r<0$ indicates an inversely proportional correlation, and a value of $r>0$ indicates a direct correlation, where the closer the value is to 1 the stronger the relationship, and the closer the $r$ value is to 0 , the weaker the correlation is [50].

System optimization requires that research studies be turned into concrete applications; as such, it is important to look at the benefits to the management of the system from the findings of these studies, as done by [51,52]. Based on the results of the water quality assessment of the VP River in the dry and rainy periods, this study also conducted a reflection on the perspectives for using the data collected in the management of stormwater and water resources in the Federal District, pointing out some managerial insights.

\section{Results and Discussion}

\subsection{Rainfall and Runoff Analysis}

The event's characteristics are shown in Table 2. It is noted that the rainfall characteristics are remarkably diverse and the maximum rainfall intensity occurred on 3 April 2018, $39.40 \mathrm{~mm} / \mathrm{h}$, with a higher average intensity of $14.39 \mathrm{~mm} / \mathrm{h}$. However, this event did not present a high peak flow either a high runoff coefficient, which may have happened due to the variability of rainfall distribution along the watershed, or high infiltration rates as a result of the soil being dry, given that the event had five ADD (antecedent dry days).

Table 2. Rainfall and Runoff characteristics for event monitored.

\begin{tabular}{|c|c|c|c|c|c|c|c|}
\hline Event & $\begin{array}{c}\text { Average Vol. } \\
\text { Rainfall }\end{array}$ & $\begin{array}{l}\text { Average } \\
\text { Intensity } \\
\text { Rainfall }\end{array}$ & $\begin{array}{c}\text { Max Intensity } \\
\text { Rainfall }\end{array}$ & ADD & Peak Flow & Runoff Vol. & Runoff Coef. \\
\hline 1 August 2018 & - & - & - & 74 & 1.29 & $85,003.96$ & - \\
\hline 1 June 2019 & - & - & - & 13 & 0.9 & $73,936.94$ & - \\
\hline 19 June 2019 & - & - & - & 31 & 0.81 & $68,362.27$ & - \\
\hline 12 August 2019 & - & - & - & 81 & 0.8 & $59,201.82$ & - \\
\hline 29 August 2019 & - & - & - & 101 & 0.5 & $41,841.93$ & - \\
\hline 19 February 2018 & 14.33 & 9.01 & 24.00 & 1 & 40.94 & $258,735.72$ & 0.20 \\
\hline 4 March 2018 & 17.20 & 14.39 & 39.40 & 5 & 9.14 & $347,488.35$ & 0.32 \\
\hline 13 March 2018 & 4.40 & 7.64 & 10.40 & 4 & 10.7 & $151,830.15$ & 0.38 \\
\hline 15 November 2018 & 17.40 & 5.04 & 8.88 & 5 & 6.81 & $64,541.48$ & 0.04 \\
\hline 18 February 2019 & 12.10 & 5.40 & 11.70 & 2 & 72.17 & $321,776.75$ & 0.30 \\
\hline 2 January 2020 & 32.33 & 9.16 & 15.85 & 1 & 53.96 & $346,177.43$ & 0.12 \\
\hline
\end{tabular}

In the dry period, peak flows are low due to the lack of rainfall, which causes runoff from all surfaces in the watershed. The runoff volume displayed in Table 2 for the dry season events is related to the base flow during one day ( $24 \mathrm{~h}$ monitoring). It was observed that the greater the ADD number is, the less water is available from the aquifers, except for the event on 1 June 2019. During the flood events, the maximum peak flow was $72.17 \mathrm{~m}^{3} / \mathrm{s}$, and the maximum runoff volume reached $347,488.35 \mathrm{~m}^{3}$ for a single monitored event, which represents five times the average for the base flow volume measured over $24 \mathrm{~h}$ in the dry season, but occurring in only a few hours ( $4 \mathrm{~h}$ flood wave). Therefore, it is possible to compare the peak flow monitoring results in Figure 2, where the axes show how high 
the flows are during a flood event, which can have many impacts on the rivers, such as erosion and diffuse pollution.

(a)

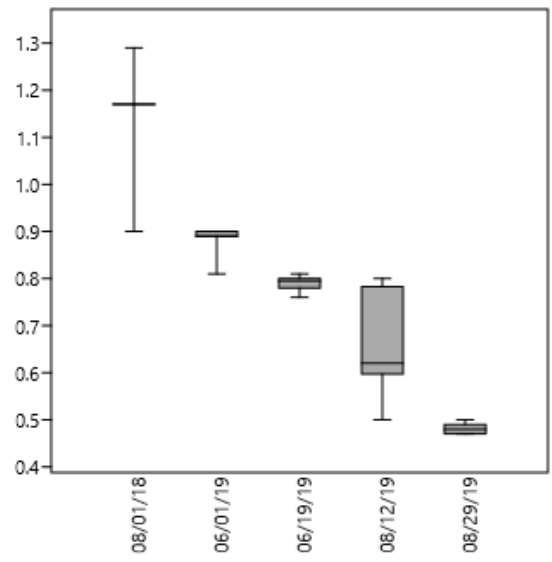

(b)

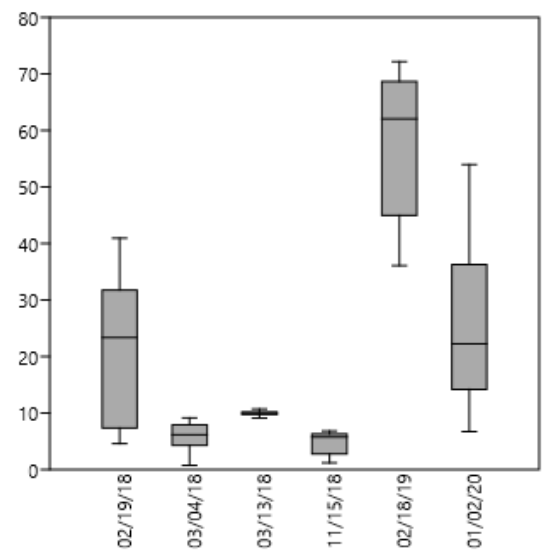

Figure 2. Flow distribution $\left(\mathrm{m}^{3} / \mathrm{s}\right)$ in each monitoring event, separated into dry (a) and flood (b) events.

\subsection{EMC Analysis}

In Table 3 it was observed that the EMC for phosphorus, RP, and TP reached their maximum values of 0.07 and $0.15 \mathrm{mg} / \mathrm{L}$, respectively, lower than the ones found in the urban direct runoff [10]. Even so, the TP and RP EMC values are similar to those found in urban areas with controlled domestic sewage, which range from 0.01-1.71 for TP and 0.026-0.48 for RP [53-57]. This, however, does not reflect the reality of the whole study area, where there is no full coverage of sewage collection or treatment, but rather the widespread use of septic tanks.

Table 3. EMC estimates for each event at VP River in $\mathrm{mg} / \mathrm{L}$.

\begin{tabular}{|c|c|c|c|c|c|c|c|c|c|c|}
\hline & Event & $\mathbf{R P}$ & TP & $\mathrm{NO}_{-2}-\mathrm{N}$ & $\mathrm{NO}_{-3}-\mathrm{N}$ & $\mathrm{NH}_{3}-\mathbf{N}$ & SS & TS & DS & COD \\
\hline \multirow{5}{*}{ ¿্厶 } & 1 August 2018 & 0.05 & 0.09 & 0.01 & 1.16 & 0.05 & 1.49 & 76.01 & 74.54 & 12.40 \\
\hline & 1 June 2019 & 0.03 & 0.04 & 0.01 & 1.49 & 0.24 & 14.77 & 78.31 & 60.67 & 32.05 \\
\hline & 19 June 2019 & 0.02 & 0.06 & 0.02 & 1.17 & 0.25 & 11.93 & 98.02 & 86.09 & 22.30 \\
\hline & 12 August 2019 & 0.07 & 0.02 & 0.03 & 0.79 & 0.08 & 3.83 & 51.21 & 50.60 & 8.70 \\
\hline & 29 August 2019 & 0.05 & 0.11 & 0.01 & 1.10 & 0.17 & 5.31 & 108.17 & 97.29 & 6.88 \\
\hline \multirow{6}{*}{$\begin{array}{l}n \\
0 \\
0 \\
0 \\
1\end{array}$} & 19 February 2018 & 0.03 & 0.10 & 0.02 & 0.16 & 0.18 & 2919.23 & 3492.01 & 1084.41 & 297.38 \\
\hline & 4 March 2018 & 0.02 & 0.05 & 0.01 & 0.12 & 0.12 & 1721.44 & 2984.78 & 1185.82 & 238.32 \\
\hline & 13 March 2018 & 0.02 & 0.02 & 0.01 & 0.21 & 0.08 & 221.13 & 389.05 & 76.20 & 34.78 \\
\hline & 15 November 2018 & 0.07 & 0.15 & 0.00 & 0.17 & 0.13 & 1132.53 & 1411.95 & 379.89 & 116.12 \\
\hline & 18 February 2019 & 0.04 & 0.10 & 0.01 & 0.08 & 0.14 & 1767.49 & 4130.12 & 2362.63 & 382.05 \\
\hline & 2 January 2020 & 0.02 & 0.09 & 0.01 & 0.43 & 0.33 & 2666.36 & 2991.09 & 350.44 & 341.74 \\
\hline
\end{tabular}

Regarding nitrogen, it was observed that during dry periods the nitrate stands out with high concentrations, as the maximum $\mathrm{NO}_{-3}-\mathrm{N} E M C$ found was $1.49 \mathrm{mg} / \mathrm{L}$ for a dry season event. Comparing to the maximum concentration during a flood event, $0.43 \mathrm{mg} / \mathrm{L}$, it is concluded that this is probably due to the dilution caused by the large volume of surface runoff transported during floods. The nitrate $E M C$ values are similar to the results obtained for predominantly residential areas, in suburban regions larger than 40 ha [58]. Meanwhile, ammonia results showed very low values when compared with the data from the Jardim Vista Alegre watershed in São Paulo, also an urbanized watershed [53], probably due to the nitrification that occurred up until the collection point in the VP River, and it also presents similarities with construction areas in the USA in the stage of clearing and grubbing [58], exactly the stage of installation of stormwater drainage systems at the moment of data collection in the VP watershed. 
The $E M C$ values for solids, in general, are higher at the higher flow rates and are strongly influenced by runoff. Even during flood events, with flows as low as $10 \mathrm{~m}^{3} / \mathrm{s}$, there was a great variation of EMC for solids. However, it is still higher than any event that happened during the dry period. The $E M C$ values for flood events were higher than those found for runoff of surfaces such as roofs $(29 \mathrm{mg} / \mathrm{L})$, terraces $(490 \mathrm{mg} / \mathrm{L})$, and streets (498 mg/L) [59]. These EMCs can be attributed to erosion phenomenon on the banks of the river in the VP watershed, a fact also identified in the Saquarema stream in the city of Belo Horizonte [60]. The EMC values for SS obtained for the VP watershed are also similar to those of areas in the USA where the predominant land use and cover correspond to areas under construction during the initial stages, such as clearing and grubbing [58].

During the flood events, the $E M C$ values for COD were higher than in the dry periods, with a maximum of $382.05 \mathrm{mg} / \mathrm{L}$ and $32.05 \mathrm{mg} / \mathrm{L}$, respectively. The $E M C$ values are similar to those of Saquarema stream in flood periods, $87-340 \mathrm{mg} / \mathrm{L}$, even when at the dry period the EMC for COD increased [60], which was not verified in the VP River, due to the relative control of sewage discharge during the dry period, when the septic tanks work properly.

Furthermore, EMC values for COD are lower than the ones found in the Jardim Vista Alegre (281.34-874.18 mg/L) and Campos Lemos (231.12-644.72 mg/L) watersheds [53], probably because of a minor discharge of untreated sewage into the VP River. GromaireMertz et al., (1999) [59] investigated the EMC for different surfaces and reported that the site that produces the higher $E M C$ for COD is streets, with an average of around $131 \mathrm{mg} / \mathrm{L}$, followed by terraces $(95 \mathrm{mg} / \mathrm{L})$, and lastly roofs $(31 \mathrm{mg} / \mathrm{L})$, corroborating that the washing off of these surfaces provides a large discharge of organic matter, not only wastewater from households.

It was observed that runoff volume dilutes the nutrients (nitrogen and phosphorus) because of the large increase in the available volume. In the dry period, in addition to constant flow rates or with exceptionally low variations, all parameters also show steady concentrations, representing the water quality characteristics of the base flow. It is important to point out that when a non-regular variation had been observed, then it would not have been caused by a point source discharge, such as a large effluent discharge from a wastewater treatment plant, for example. Thus, it can be assumed that if a discharge is occurring, it is an illegal, diffuse source, and continuous over time.

Huang et al., (2007) [61] investigated the characteristics of runoff in an urban basin in Macau and found that the greatest rainfall with the highest number of antecedent dry days (ADD) had the highest EMC for nitrogen, suspended solids, and organic matter. Therefore, the influence of hydrological parameters on monitored water quality was also analyzed for each season studied.

The EMC for the dry season demonstrated strong correlations between the quality parameters (Figure 3). The correlation coefficients found were as follows: $r=0.93$ for $\mathrm{NH}^{+3}-\mathrm{N}$ and SS; $\mathrm{r}=0.72$ for $\mathrm{NH}^{+3}-\mathrm{N}$ and COD; $\mathrm{r}=0.57$ for $\mathrm{NH}^{+3}-\mathrm{N}$ and TS; $\mathrm{r}=0.64$ for $\mathrm{NH}^{+3}-\mathrm{N}$ and $\mathrm{NO}^{-3}-\mathrm{N}$; and $\mathrm{r}=0.82$ for $\mathrm{NO}^{-3}-\mathrm{N}$ and COD. These values indicate that these pollutants probably came from the same source, which, during the dry season, might be associated with sewage discharges. TP presented a correlation with DS $(r=0.84)$ and TS $(r=0.71)$, indicating that it is associated with sediments. Comparing EMC values with hydrological data, the connection of baseflow volume in the cross-section with COD $(\mathrm{r}=0.50)$ and with $\mathrm{NO}^{-3}-\mathrm{N}(\mathrm{r}=0.40)$ is noted, indicating that the greater the volume crossing the monitored section is, the greater is the concentration of pollutants.

Analyzing the EMC correlation with hydrological data of the flood events (Figure 4), it is noted the importance of rainfall in the water quality of the VP River. The greater the average rainfall volume, the higher the $E M C$ values for $\mathrm{NH}^{+3}-\mathrm{N}(\mathrm{r}=0.90), \mathrm{NO}_{-3}-\mathrm{N}$ $(\mathrm{r}=0.72)$, SS $(\mathrm{r}=0.65)$ and COD $(\mathrm{r}=0.52)$. COD and SS are strongly correlated, as well as ammonia and nitrate, which can be attributed to possible discharges from overflowing septic tanks that have a limited capacity and, with abnormal rainfall events, can discharge their exceeding volume directly into the stormwater drainage system. 


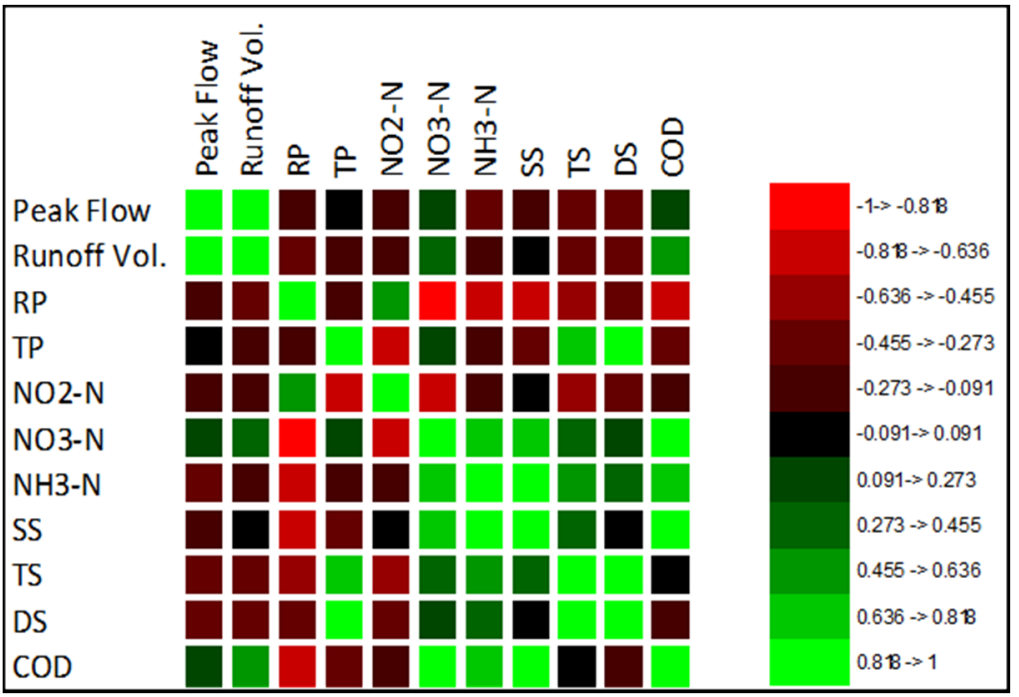

Figure 3. Correlation between the hydrological and the water quality characteristics (EMC) during the dry period.

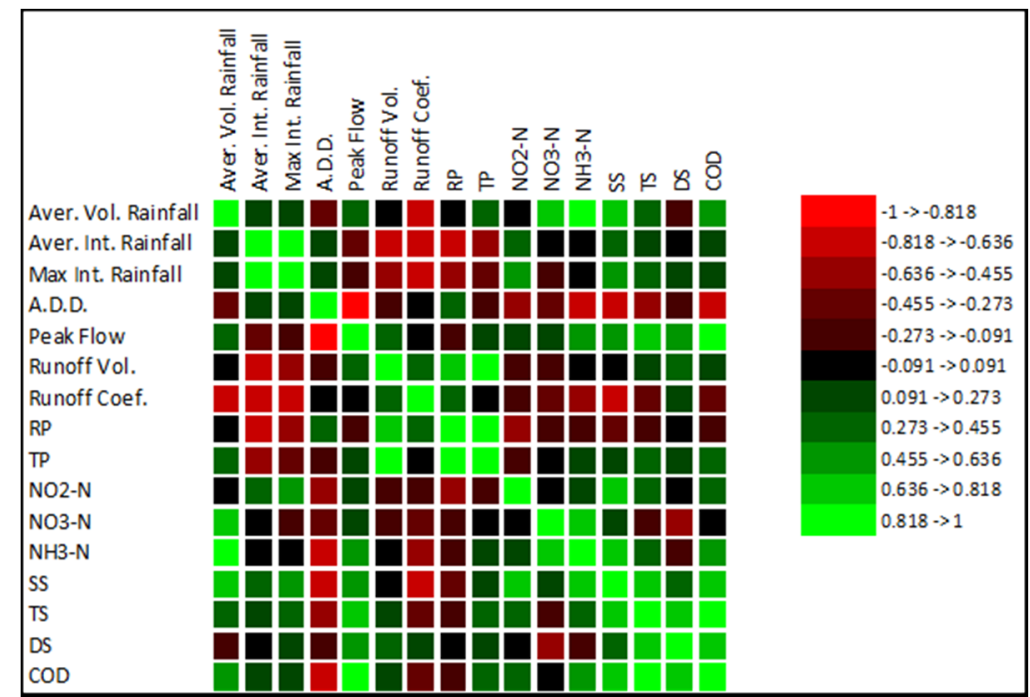

Figure 4. Correlation between the hydrological data and the water quality characteristics during floods.

Regarding diffuse pollution, the correlation between pollutants and peak flow is an analysis that can be associated with the drag force during surface washing. It was observed that the strongest peak flow correlations were with COD $(r=0.86), T S(r=0.74)$, and DS $(r=0.62)$, corroborating that the highest concentrations of solids and organic matter occur in events with greater flow rates. The greatest volumes of surface runoff flow resulted in greater $E M C$ values for $\mathrm{RP}(\mathrm{r}=0.765)$ and $\mathrm{TP}(\mathrm{r}=0.89)$, probably because this flow suspends sediments at the bottom of the riverbed, releasing the pollutants associated with them.

The number of antecedent dry days (ADD) is often analyzed in the scientific literature because it is directly associated with diffuse pollution due to the phenomenon known as build-up, the accumulation of pollutants on the surface. In the present study, it was observed that the greater the ADD number, the lower the peak flow $(r=-0.84)$. This is associated with increased infiltration, due to the fact that dry soil is able to retain more rainfall volume, which is why ADD do not influence discharged pollution as much since the reduction in surface flow causes the loads discharged in the VP River to also decrease.

The present study did not find any high value of EMC for SS correlation with ADD, rainfall duration, volume, or intensity, a result similar to the experimental study developed 
in a residential watershed in France [59]. However, when associating SS concentrations with hydrological parameters, the strongest correlation corresponds to that with the average volume of rainfall, emphasizing that the concentration is associated with the flow rate, i.e., diffuse pollution. Park et al., (2019) [62] also calculated correlations between hydrological and water quality parameters obtaining high correlation values between total rainfall volume and intensity, and between flow rate and SS, as seen in the VP River.

\subsection{First Flush Analysis}

The behavior of the first flush is quite heterogeneous when comparing the dry and flood season events, and even within the same event for the different pollutants. The event on 19 February 2018 presents all curves above the $45^{\circ}$ bisector, except for nitrite. That result diverges from those on 1 August 2018, 18 February 2019 and 2 January 2020, where most curves are situated below the bisector (Figure 5).
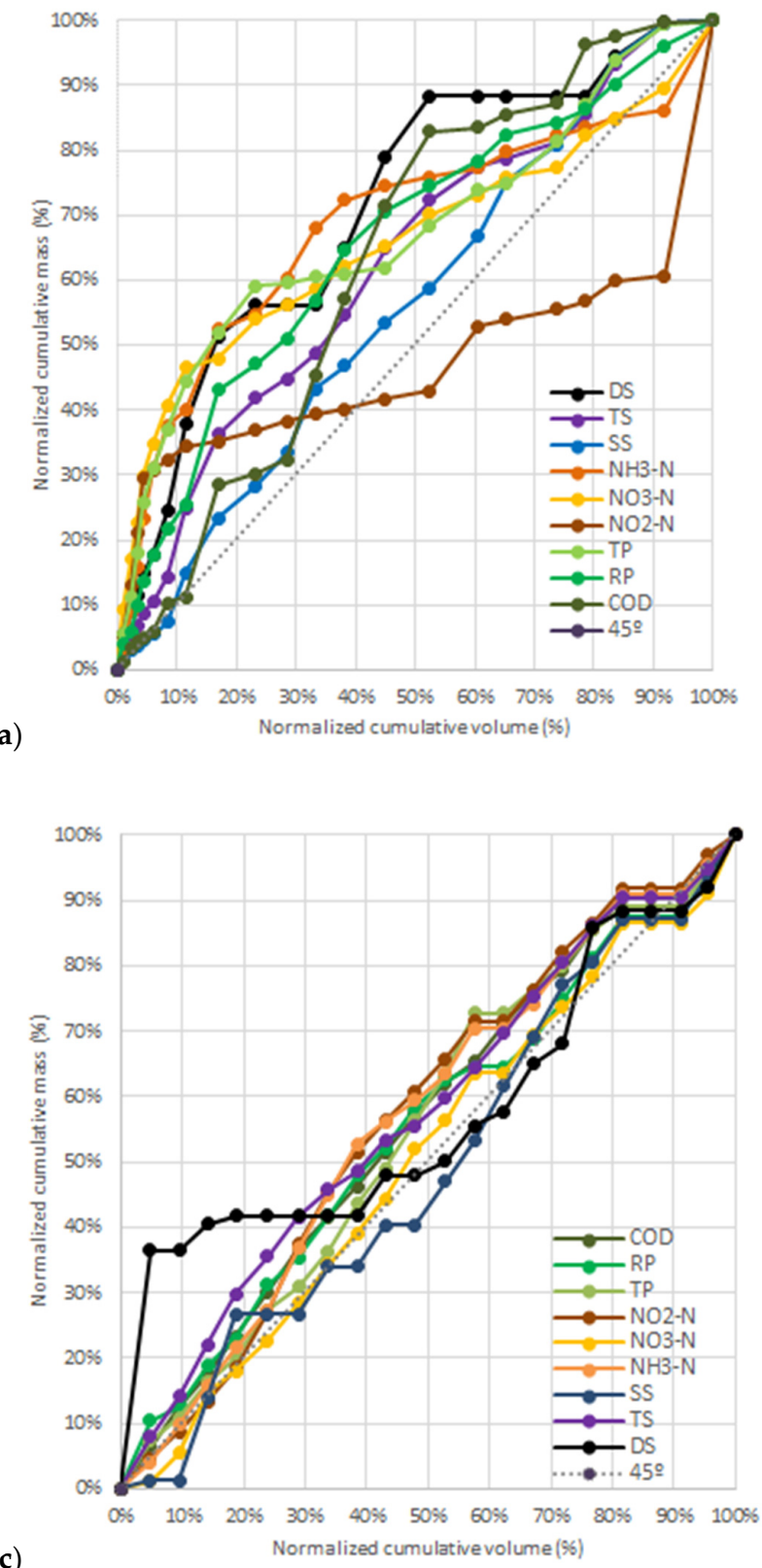

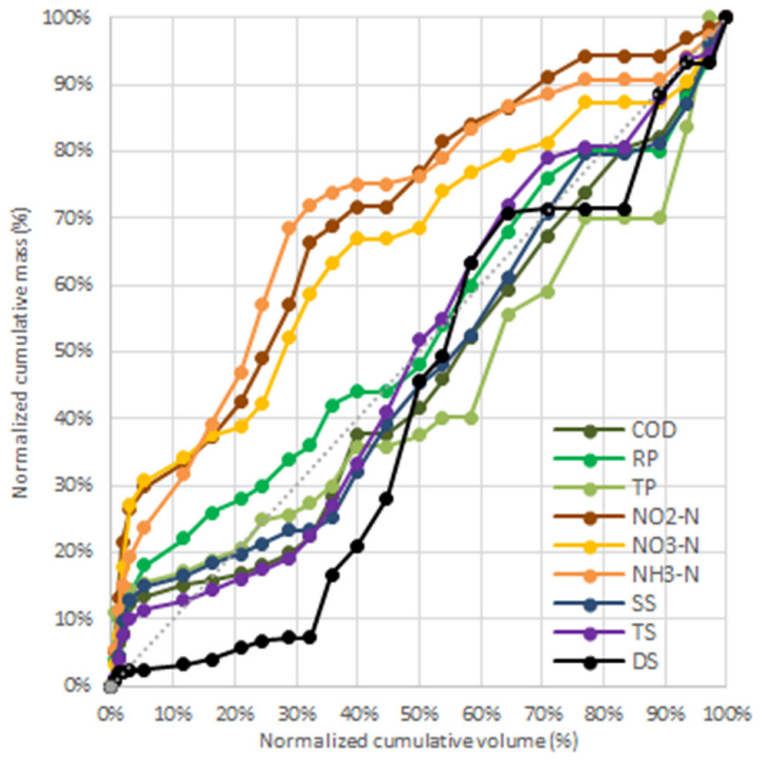

(b)

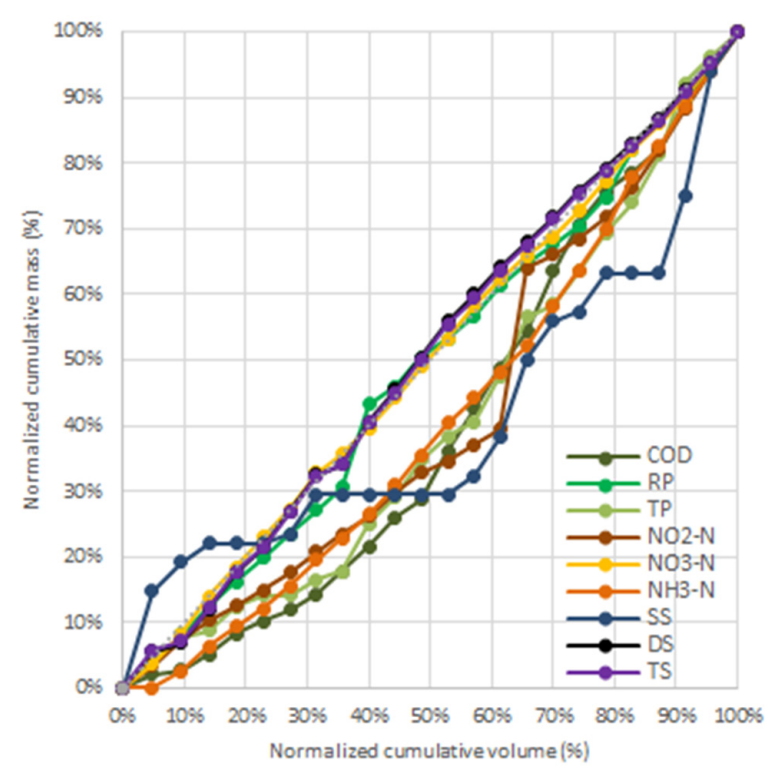

Figure 5. Cont. 

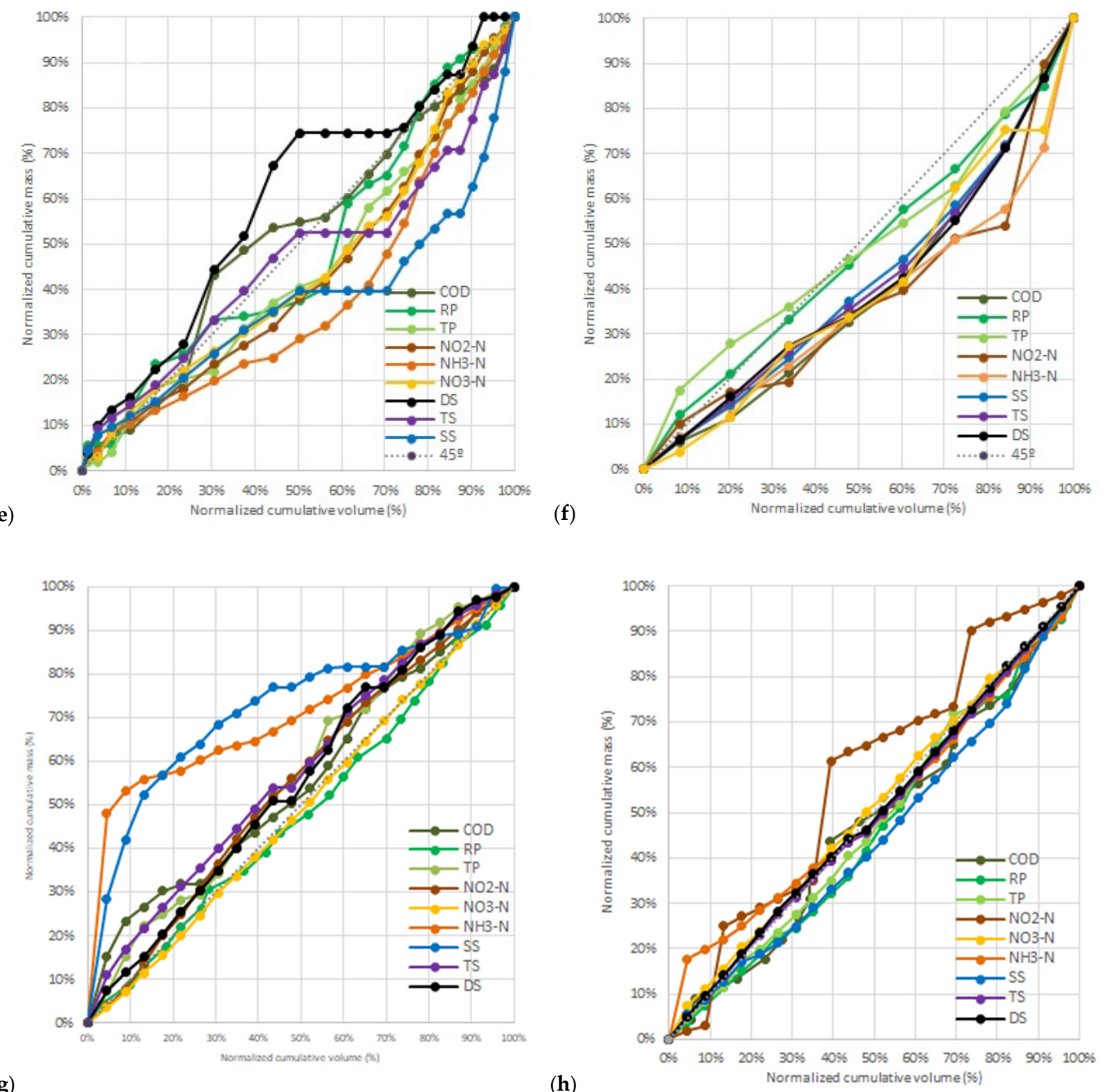

(g)

(h)

Figure 5. Cont. 

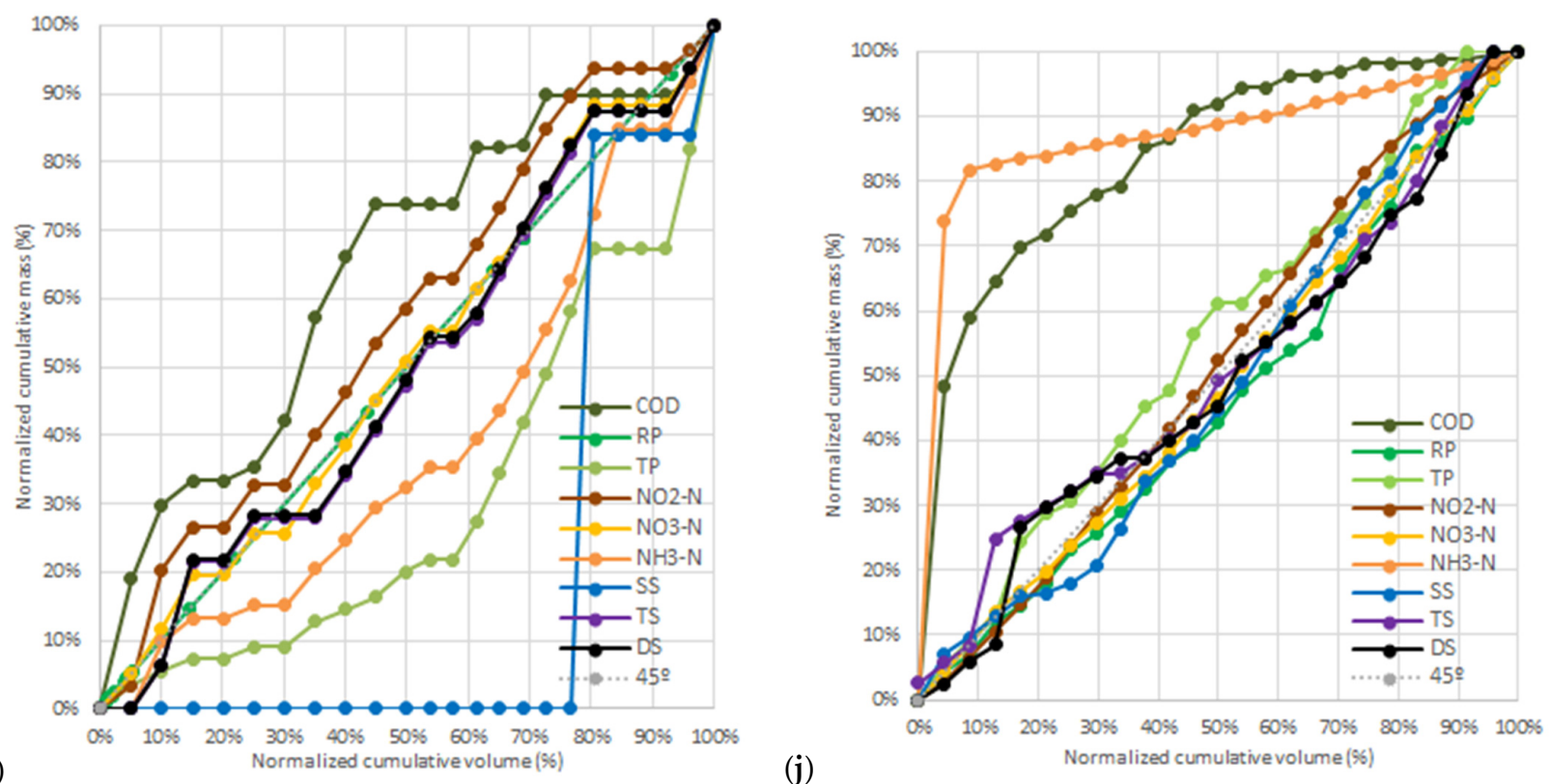

(i)

$(\mathbf{j})$

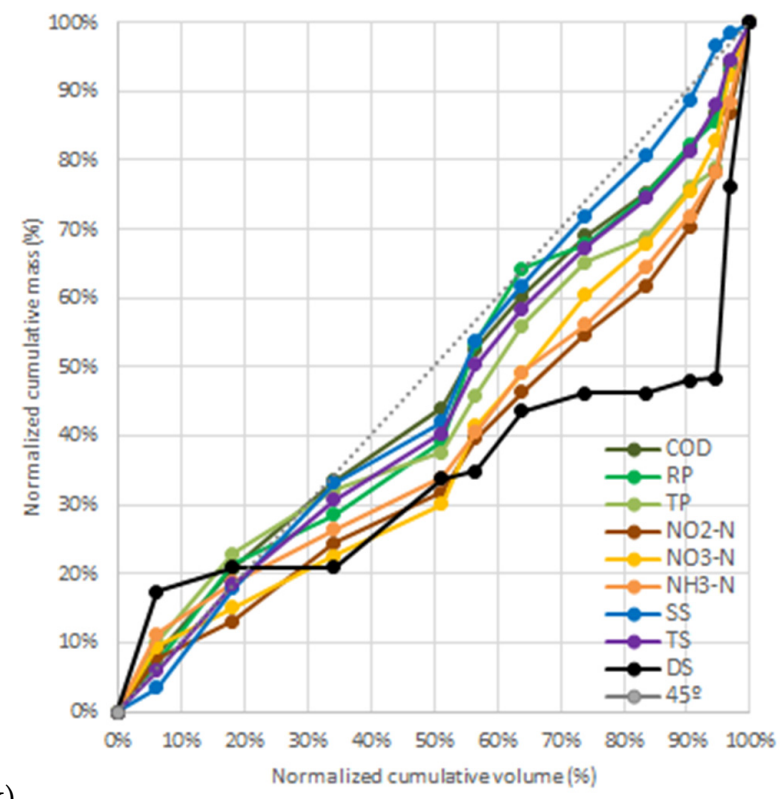

$(\mathbf{k})$

Figure 5. First flush effect during each event: (a)19 February 2018; (b) 4 March 2018; (c) 13 March 2018; (d) 1 August 2018; (e) 15 November 2018; (f) 18 February 2019; (g) 1 June 2019; (h) 19 June 2019; (i) 12 August 2019; (j) 29 August 2019; (k) 2 January 2020.

Bertrand-Krajewski et al. (1998) [49] determine the identification of the phenomenon with the $80 / 30$ fraction. In this case, only the event that occurred on 29 August 2019 would present FF for two pollutants: $\mathrm{NH}^{+3}-\mathrm{N}$ and COD, which limits the definition of the first flush. According to the definition of [46], first flush occurs when the $M(V)$ curves are above the bisector, which would result in the identification of FF in all monitored events. When analyzed for parameter b, the occurrence of FF is confirmed, as b was less than 1 in 20 of the 45 curves (44\%) for events monitored in the dry season, and 42 of the 54 curves $(77 \%)$ for events monitored in the flood season.

Di Modugno et al., (2015) [63] reported that in the monitored events an average of the first $30 \%$ of the volume carries approximately $60 \%$ of SS. In the present research, what the results showed about FF was: for the first $30 \%$ of the initial volume, around $29.33 \%$ of SS 
were carried during flood events (Table 4), and this is the lowest percentage. For $\mathrm{NH}^{+3}-\mathrm{N}$ and $\mathrm{RP}$, the greatest portions were $38.33 \%$ and $35 \%$, respectively.

Table 4. Percentage of the mass of pollutants discharged in the first $30 \%$ of the volume of each analyzed event.

\begin{tabular}{cccccccccc}
\hline Event & PR & PT & $\mathbf{N O}_{\mathbf{2}}-\mathbf{N}$ & $\mathbf{N O}_{\mathbf{3}}-\mathbf{N}$ & $\mathbf{N H}_{\mathbf{3}}-\mathbf{N}$ & $\mathbf{S S}$ & $\mathbf{S T}$ & $\mathbf{S D}$ & $\mathbf{D Q O}$ \\
\hline 19 February 2018 & 50 & 60 & 38 & 55 & 60 & 34 & 44 & 55 & 32 \\
4 March 2018 & 34 & 26 & 60 & 52 & 70 & 28 & 20 & 7 & 20 \\
13 March 2018 & 35 & 29 & 40 & 30 & 37 & 27 & 42 & 42 & 37 \\
15 November 2018 & 33 & 22 & 24 & 26 & 20 & 37 & 39 & 44 & 43 \\
18 February 2019 & 32 & 30 & 19 & 22 & 20 & 21 & 22 & 23 & 20 \\
2 January 2020 & 26 & 30 & 21 & 21 & 23 & 29 & 28 & 21 & 30 \\
Average & 35.00 & 32.83 & 33.67 & 34.33 & 38.33 & 29.33 & 32.50 & 32.00 & 30.33 \\
\hline
\end{tabular}

The values for $\mathrm{b}$ and the hydrological parameters, rainfall and flow rate, were correlated to assess whether a greater intensity of rainfall would influence the process of removal of soil particles and in the magnitude of the diffuse pollution, as stated by $[64,65]$. Analyzing Figures S1 and S2, found in the supplementary files, it can be seen that the greater the maximum or mean rainfall intensity is, the lower are the values of $b$ for most pollutants, which was also identified by [66-69]. The only exception was DS, which can be associated with dilution issues.

It is perceived that the greater the number of antecedent dry days is, the lower is the value of $b$ (that is, the greater is the occurrence of $F F$ ) for some pollutants, such as $R P$, $\mathrm{NH}_{3}-\mathrm{N}$, SS, and COD. This was also identified by [8] for the RF I watershed, where the event that had the lowest values of $b$ also had the greater number of antecedent dry days, around 25 days. As confirmed by [64], the lowest values of b occurred more frequently after a long antecedent dry period, and according to [69] the number of antecedent dry days and the maximum rainfall intensity are the parameters that most affect the occurrence of FF.

Regarding the flow parameters, it is noted that the greater the peak flow and the flow volume are, the harder it is to characterize FF. This occurred in the event with the greatest flow rate, in 18 February 2019, which can be attributed to the great stormwater volumes in the event, causing a greater drag force, and also more dilution of the pollutants.

Despite the various, and sometimes ambiguous, definitions of first flush, researchers, policymakers, and watershed stakeholders widely recognize the potential of the knowledge about FF to promote more effective and economic implementation of practices to control river water quality, such as structures built with green infrastructure technology, since compensatory techniques for urban drainage have a limitation regarding the volumes they can retain $[10,70-72]$.

\subsection{Managerial Insights}

The assessment of water quality in the VP River resulted in a real dataset that can support managers in the decision-making process. Some assumptions that can be drawn from the results of this research regarding stormwater management and water resources are:

1. The monitoring of water bodies during flood events is fundamental for the analysis of parameter compliance to quality standards and should be incorporated into water resource management plans;

2. Correlations between water quality parameters can be used to simplify monitoring when continuous monitoring is needed, but the subject may require more in-depth studies for each specific situation;

3. Investments in better sewage collection/treatment and urban water management systems are essential for mitigation of the environmental impacts of effluents, but they must be carried out paired with the urban expansion and always include measures to reduce the construction environmental impacts; 
4. Structures planned to retain the first volumes of runoff can be important for improving the quality of receiving water bodies, but must be hydraulically well designed and engineered;

5. SUDS should be designed and implemented from the beginning of new urban settlements, but adapting existing stormwater management systems to become more sustainable is a viable option for controlling water pollution in the Federal District.

\section{Conclusions}

Based on the various parameters evaluated, this study concluded that the physical and chemical characteristics of the river water associated with rainfall and runoff data can characterize the diffuse pollution generated in the VP watershed, an area undergoing a rapid urbanization process in Brasilia, Brazil. In addition, the EMC values and the ratios between volume and pollutant mass transported found led to some conclusions about the behavior of pollutant concentrations in the VP river and the occurrence of the first flush phenomenon.

It was observed that the seasonal distribution pattern of different parameters was influenced by different anthropic factors. In the dry season, the concentration of organic matter and nutrients is higher due to the continuous discharge of untreated sewage into the river. In the rainy season the phenomenon of erosion stands out, being attributed to the large volumes of runoff, and the concentrations of nutrients and organic matter in the river are still high during rainy events, possibly induced by the overflow of septic tanks. These issues are associated with the rapid expansion of settlements linked to the lack of effective land-use management strategies.

The installation of sewage collection and treatment and urban drainage systems aims to reduce nutrient and organic matter pollution in the VP River, but in the monitored flood events, high sediment loads produced in the watershed were found, which are associated with the construction of these urban infrastructure networks that still takes place today, with constant excavation and earthworks resulting in high concentrations of SS. Therefore, the construction of the sewage and stormwater collection networks caused a high impact on the observed water quality, but on the other hand with the wastewater collection provided by the installation of the sewage network a decrease in COD concentrations was noticed over time in the dry period.

Compared to other studies, the $E M C$ values found for the VP watershed were lower than those of two other Brazilian urban watersheds for ammonia and COD, but similar to those found in a small urban watershed in Brazil during flood events for COD and to those found in an area under construction also in the rainy season for SS.

Confirmation of the occurrence of FF in the VP watershed and the calculated volumeto-mass ratios for the pollutants help establish directions for sizing Low Impact Development devices used to achieve pollutant reduction goals, improve sampling methodologies for water quality assessment, and support the delineation of stormwater management strategies by public authorities.

The correlation values found in the study showed a significant increase/decrease of one parameter over the other. Rainfall events cause large floods that wash off pollutants through impervious urban areas. Large rainfall volumes generate high EMC values for ammonia, nitrate, SS, and COD; the latter two are also associated with high peak flows. Correlation analysis also showed that the higher the rainfall intensity and the number of ADDs, the higher the occurrence of FF for reactive phosphorus, ammonia, SS, and COD.

Finally, it was possible to identify management insights arising from the results of the study, mainly related to monitoring techniques and pollution control measures. In summary, the analysis of the EMC and FF and the correlation between them and the precipitation and runoff characteristics of monitored events provide valuable information for the management of water resources in the Federal District, in particular with regard to water pollution control in the VP river basin, and highlights the importance of continuous 
monitoring of water quality in rainy periods for the purposes of stormwater management and diffuse pollution mitigation.

Supplementary Materials: The following are available online at https:/ / www.mdpi.com/article/ 10.3390/w13182552/s1, Figure S1: Correlation between the hydrological and the FF characteristics during dry events, Figure S2: Correlation between the hydrological and the FF characteristics during rainy events.

Author Contributions: Conceptualization: M.E.L.C.; Methodology: M.E.L.C. and S.K.; Monitoring and Modelling: M.E.L.C. and D.J.C.; Formal Analysis: M.E.L.C. and S.K.; Writing-Original Draft Preparation: D.J.C. and M.E.L.C.; Writing—Review \& Editing: S.K.; Supervision: S.K. All authors have read and agreed to the published version of the manuscript.

Funding: This research was funded by Brazilian Coordination for the Improvement of Higher Education (CAPES) and ANA (Sanitation and Water National Agency). The Brazilian National Council for Scientific and Technological Development (CNPq), the Federal District Research Support Foundation (FAP-DF), and the University of Brasília (UnB).

Acknowledgments: We acknowledge to FAPDF, FINEP, CNPq, FUNAPE, The authors are also grateful to ANA, Caesb, Novacap, and Adasa for data collection support.

Conflicts of Interest: The authors declare no conflict of interest.

\section{References}

1. Barbosa, A.E.; Fernandes, J.N.; David, L.M. Key issues for sustainable urban stormwater management. Water Res. 2012, 46, 6787-6798. [CrossRef]

2. Zhang, L.; Ye, Z.; Shibata, S. Assessment of Rain Garden Effects for the Management of Urban Storm Runoff in Japan. Sustainability 2020, 12, 9982. [CrossRef]

3. Qi, Y.; Chan, F.K.S.; O’Donnell, E.C.; Feng, M.; Sang, Y.; Thorne, C.R.; Griffiths, J.; Liu, L.; Liu, S.; Zhang, C.; et al. Exploring the Development of the Sponge City Program (SCP): The Case of Gui'an New District, Southwest China. Front. Water 2021, 3, 41. [CrossRef]

4. Zambrano, K.T.; Poleto, C.; Oliveira, J.N. A comparative analysis on water quality in an urban micro watershed. Manag. Environ. Qual. Int. J. 2017, 28, 566-578. [CrossRef]

5. Kosak, C. Water Quality Assessment and Its Effects on Diffuse Pollution Considering a New Water Quality and Quantity Approach. Master's Thesis, Federal University of Paraná (UFPR), Curitiba, Brazil, 2016.

6. Okaikue-Woodi, F.E.K.; Cherukumilli, K.; Ray, J.R. A critical review of contaminant removal by conventional and emerging media for urban stormwater treatment in the United States. Water Res. 2020, 187, 116434. [CrossRef] [PubMed]

7. Vidal, I.C.A.; de Oliveira, R.; Coura, M.A.; Rodrigues, A.C.L.; Costa Filho, F.C.; Camelo, S.M. Degradation of the macro-drainage water quality of an urban basin in Northeastern Brazil. Environ. Dev. Sustain. 2021, 23, 4342-4356. [CrossRef]

8. Tsuji, T.M. Monitoramento E Modelagem Das Águas De Drenagem Pluvial No Núcleo Urbano Da Bacia Do Ribeirão Riacho Fundo, Brasília-DF. Programa de Pós-Graduação em Tecnologia Ambiental e Recursos Hídricos. Master's Thesis, Universidade de Brasília (UnB), Brasília, Brazil, 2018. (In Portuguese)

9. Tsuji, T.M.; Costa, M.E.L.; Koide, S. Diffuse pollution monitoring and modelling of small urban watershed in Brazil Cerrado. Water Sci. Technol. 2019, 79, 1912-1921. [CrossRef]

10. Righetto, A.; Gomes, K.; Sousa, F.F.R. Poluição difusa nas águas pluviais de uma bacia de drenagem urbana. Eng. Sanitária E Ambient. 2017, 22, 1109-1120. [CrossRef]

11. Costa, M.E.L.; Souza, F.P.; Roque, D.F.D.; Koide, S. Analysis of urban stormwater runoff quality and first flush phenomenon. In Proceedings of the 14th IWA/IAHR ICUD-International Conference on Urban Drainage, Prague, Czech Republic, 10-15 September 2017; pp. 465-472.

12. Souza, F.P.; Costa, M.E.L.; Koide, S. Hydrological Modelling and Evaluation of Detention Ponds to Improve Urban Drainage System and Water Quality. Water 2019, 11, 1547. [CrossRef]

13. Zhao, J.; Chen, Y.; Hu, B.; Yang, W. Mathematical Model for Sediment Wash-Off from Urban Impervious Surfaces. J. Environ. Eng. 2016, 142, 04015091. [CrossRef]

14. Glick, R.H. Impacts of Impervious Cover and Other Factors on Storm-Water Quality in Austin, Tex. J. Hydrol. Eng. 2009, 14, 316-323. [CrossRef]

15. Field, R.; Pitt, R.; Lalor, M.; Brown, M. Investigation of Dry-Weather Pollutant Entries into Storm-Drainage Systems. J. Environ. Eng. 1994, 120, 1044-1066. [CrossRef]

16. Todd, D.A.; Bediente, P.B.; Haasbeek, J.F.; Noell, J. Impact of Land Use and NPS Loads on Lake Quality. J. Environ. Eng. 1989, 115, 633-649. [CrossRef] 
17. Haft, A.; Wallach, R.; Friedler, E.; Zinger, Y. Land use impact on urban runoff in a Mediterranean city-Kfar-Saba, Israel as a case study. In Proceedings of the 14th IWA/IAHR ICUD-International Conference on Urban Drainage, Prague, Czech Republic, 10-15 September 2017.

18. Lee, J.H.; Bang, K.I. Characterization of urban stormwater runoff. Water Res. 2000, 34, 1773-1780. [CrossRef]

19. Brown, R.R.; Keath, N.; Wong, T.H.F. Urban water management in cities: Historical, current and future regimes. Water Sci. Technol. 2009, 59, 847-855. [CrossRef]

20. Xing, Y.-J.; Chen, T.-L.; Gao, M.-Y.; Pei, S.-L.; Pan, W.-B.; Chiang, P.-C. Comprehensive Performance Evaluation of Green Infrastructure Practices for Urban Watersheds Using an Engineering-Environmental-Economic (3E) Model. Sustainability 2021, 13, 4678. [CrossRef]

21. Candela, A.; Freni, G.; Mannina, G.; Viviani, G. Quantification of diffuse and concentrated pollutant loads at the watershed-scale: An Italian case study. Water Sci. Technol. 2009, 59, 2125-2135. [CrossRef] [PubMed]

22. Saloranta, T.M.; Kamara, J.; Rekolainen, S.; Malve, O. Benchmark criteria: A tool for selecting appropriate models in a field of water management. Environ. Manag. 2003, 32, 322-333. [CrossRef]

23. Batroney, T.; Wadzuk, B.M.; Traver, R.G. Parking Deck's First Flush. J. Hydrol. Eng. 2010, 15, 123-128. [CrossRef]

24. Martino, G.D.; De Paola, F.; Fontana, N.; Marini, G.; Ranucci, A. Pollution Reduction in Receivers: Storm-Water Tanks. J. Urban Plan. Dev. 2011, 137, 29-38. [CrossRef]

25. CODEPLAN (Companhia De Planejamento Do Distrito Federal). PDAD—Pesquisa Distrital por Amostra de Domicílios 2018; Governo Do Distrito Federal: Brasília, Brazil, 2019. (In Portuguese)

26. Lima, J.E.F.; Fonseca, S.A.; Brostel, R.C.; Cézar, M.C.M. Avaliação da disponibilidade hídrica no Distrito Federal. In Gestão da crise hídrica 2016-2018: Experiências do Distrito Federal; Lima, J.E.F.W., Ed.; Adasa, Caesb, Seagri, Emater, DF: Brasília, Brazil, 2018. (In Portuguese)

27. Olivetti, D.; Roig, H.; Martinez, J.M.; Borges, H.; Ferreira, A.; Casari, R.; Salles, L.; Malta, E. Low-Cost Unmanned Aerial Multispectral Imagery for Siltation Monitoring in Reservoirs. Remote Sens. 2020, 12, 1855. [CrossRef]

28. Borges, H.D.; Cicerelli, R.E.; de Almeida, T.L.; Roig, H.L.; Olivetti, D. Monitoring cyanobacteria occurrence in freshwater reservoir using semi-analytical algorithms and orbital remote sensing. Mar. Freshw. Res. 2018, 71, 569-578. [CrossRef]

29. Baptista, G.M.; Araujo Neto, M.D.A. O processo de eutrofização artificial no Lago Paranoá, Brasília, DF. GEONOMOS 2008, 2, 31-39. [CrossRef]

30. Ferrante, J.E.T.; Rancan, L.; Barbosa Netto, P. Meio físico. In Olhares Sobre O Lago Paranoá; Fonseca, F.O., Ed.; GDF/SEMARH: Brasília, Brazil, 2001. (In Portuguese)

31. ADASA (Agência Reguladora de Águas, Energia e Saneamento Básico do Distrito Federal). Manual de Drenagem e Manejo de Águas Pluviais Urbanas do Distrito Federal; ADASA: Brasília, Brazil, 2018. (In Portuguese)

32. EMBRAPA (Empresa Brasileira de Pesquisa Agropecuária). Mapa Pedológico Digital—SIG Atualizado do Distrito Federal Escala 1:100.000 e Uma Sintese do Texto Explicativo. Documento 120; Embrapa Cerrados: Planaltina, Brazil, 2004.

33. Nunes, G.; Minoti, R.; Koide, S. Mathematical Modeling of Watersheds as a Subsidy for Reservoir Water Balance Determination: The Case of Paranoá Lake, Federal District, Brazil. Hydrology 2020, 7, 85. [CrossRef]

34. CODEPLAN (Companhia De Planejamento Do Distrito Federal). Atlas do Distrito Federal; Governo do Distrito Federal: Brasília, Brazil, 2020; Chapter 2.

35. SEDUH (Secretaria de Estado de Desenvolvimento Urbano e Habitação). Mapa 1 A—Zoneamento PDOT; Governo do Distrito Federal: Brasília, Brazil, 2017.

36. Aquino, I.G.; Roig, H.L.; Oliveira, E.S.; Garnier, J.; Guimarães, E.M.; Koide, S. Variação temporal da descarga sólida em suspensão e identificação de minerais a partir de aperfeiçoamento de método de amostragem automática no Córrego Riacho Fundo, Brasília, Distrito Federal. Geol. USP. Série Científica 2018, 18, 171-185. [CrossRef]

37. Barbosa, J.S.B.; Bellotto, V.R.; Silva, D.B.; Lima, T.B. Nitrogen and Phosphorus Budget for a Deep Tropical Reservoir of the Brazilian Savannah. Water 2019, 11, 1205. [CrossRef]

38. Menezes, P.H.B.J.; Roig, H.L.; Almeida, T.; Neto, G.B.S.; Isaias, B. Análise da evolução do padrão de uso e ocupação do solo na bacia de contribuição do Lago Paranoá-DF. Estud. Geogr. Rev. Eletrôn. de Geogr. 2010, 8, 88-106.

39. APHA; AWWA; WEF. Standard Methods for the Examination of Water and Wastewater, 23th ed.; American Public Health Association: Washington, DC, USA; American Water Works Association: Washington, DC, USA; Water Environment Federation: Washington, DC, USA, 2017.

40. Aguilar, M.F.; Dymond, R.L. Evaluation of Stormwater Control Measure Performance Uncertainty. J. Environ. Eng. 2019, 145, 04019060. [CrossRef]

41. McCarthy, D.T.; Zhang, K.; Westerlund, C.; Viklander, M.; Bertrand-Krajewski, J.; Fletcher, T.D.; Deletic, A. Assessment of sampling strategies for estimation of site mean concentrations of stormwater pollutants. Water Res. 2018, 129, 297-304. [CrossRef]

42. Thomson, N.; McBean, E.; Snodgrass, W.; Monstrenko, I. Highway stormwater runoff quality: Development of surrogate parameter relationships. Water Air Soil Pollut. 1997, 94, 307-347. [CrossRef]

43. Novotny, V. Nonpoint Pollution and Urban Stormwater Management; Technomic Publishing Co.: Lancaster, PA, USA, $1995 ;$ Volume 9.

44. Li, C.; Liu, M.; Hu, Y.; Gong, J.; Sun, F.; Xu, Y. Characterization and first flush analysis in road and roof runoff in Shenyang, China. Water Sci. Technol. 2014, 70, 397-406. [CrossRef] 
45. Flint, K.R.; Davis, A.P. Pollutant Mass Flushing Characterization of Highway Stormwater Runoff from an Ultra-Urban Area. J. Environ. Eng. 2007, 133, 616-626. [CrossRef]

46. Deletic, A. The first flush load of urban surface runoff. Water Res. 1998, 32, 2462-2470. [CrossRef]

47. Sansalone, J.J.; Buchberger, S.G. Partitioning and First Flush of Metals in Urban Roadway Storm Water. Environ. Eng. 1997, 123, 134-143. [CrossRef]

48. Arias, M.E.; Brown, M.T.; Sansalone, J.J. Characterization of Storm Water-Suspended Sediments and Phosphorus in an Urban Catchment in Florida. J. Environ. Eng. 2013, 139, 277-288. [CrossRef]

49. Bertrand-Krajewski, J.; Chebbo, G.; Saget, A. Distribution of pollutant mass vs volume in stormwater discharges and the first flush phenomenon. Water Res. 1998, 32, 2341-2356. [CrossRef]

50. Gorgoglione, A.; Gioia, A.; Iacobellis, V. A Framework for Assessing Modeling Performance and Effects of Rainfall-CatchmentDrainage Characteristics on Nutrient Urban Runoff in Poorly Gauged Watersheds. Sustainability 2019, 11, 4933. [CrossRef]

51. Tayyab, M.; Jemai, J.; Lim, H.; Sarkar, B. A sustainable development framework for a cleaner multi-item multi-stage textile production system with a process improvement initiative. J. Clean. Prod. 2020, 246, 119055. [CrossRef]

52. Tayyab, M.; Sarkar, B. An interactive fuzzy programming approach for a sustainable supplier selection under textile supply chain management. Comput. Ind. Eng. 2021, 155, 107164. [CrossRef]

53. Porto, M.F.A.; Haupt, J.P.O.; Masini, L.S.; Barros, M.T.L. Avaliação da concentração média do evento para cargas difusas urbanas na cidade de São Paulo. In Proceedings of the 7 Simpósio de Hidráulica e Recursos Hídricos dos Países de Língua Oficial portuguesa, Évora, Portugal, 30 May-2 June 2005.

54. Baird, C.; Jennings, M.; Ockerman, D.; Dybala, T. Characterization of Nonpoint Sources and Loadings to the corpus Christi Bay National Estuary Program Study Area; Final report; Texas Natural Resource Conservation Commission: Austin, TX, USA, 1996.

55. Schueler, T.R. Controlling Urban Runoff: A Practical Manual for Planning and Designing Urban BMPs; Metropolitan Washington Council of Governments, Washington Metrop. Water resource Planning Board: Washington, DC, USA, 1997.

56. Polls, I.; Lanyon, R. Pollutant Concentrations from Homogeneous Land Uses. J. Environ. Eng. Div. 1980, 106, 69-80. [CrossRef]

57. Brezonik, P.L.; Stadelmann, T.H. Analysis and predictive models of stormwater runoff volumes, loads and pollutant concentrations from watersheds in the Twin Cities metropolitan area, Minnesota, USA. Water Res. 2002, 36, 1743-1757. [CrossRef]

58. Line, D.E.; White, N.M.; Osmond, D.L.; Jenning, G.D.; Monjonnier, C.B. Pollutant export from various land uses in Upper Neuse River Basin. Water Environ. Res. 2002, 74, 100-108. [CrossRef]

59. Gromaire-Mertz, M.C.; Garnaud, S.; Gonzalez, A.; Chebbo, G. Characterisation of urban runoff pollution in Paris. Water Sci. Technol. 1999, 39, 1-8. [CrossRef]

60. Vieira, P.D. Avaliação das Condições de Qualidade da Água em Tempo Seco e Durante Eventos de Chuvas Em Uma Microbacia Urbanizada No Município de Belo Horizonte; Universidade Federal de Minas Gerais (UFMG): Belo Horizonte, Brazil, 2008. (In Portuguese)

61. Huang, J.; Du, P.; Ao, C.; Lei, M.; Zhao, D.; Ho, M.; Wang, Z. Characterization of surface runoff from a subtropics urban catchment. J. Environ. Sci. 2007, 19, 148-152. [CrossRef]

62. Park, M.; Choi, Y.S.; Shin, H.J.; Song, I.; Yoon, C.G.; Choi, J.D.; Yu, S.J. A Comparison Study of Runoff Characteristics of Non-Point Source Pollution from Three Watersheds in South Korea. Water 2019, 11, 966. [CrossRef]

63. Di modugno, M.; Gioia, A.; Gorgoglione, A.; Iacobellis, V.; La Forgia, G.; Piccinni, A.; Ranieri, E. Build-Up/Wash-Off Monitoring and Assessment for Sustainable Management of First Flush in an Urban Area. Sustainability 2015, 7, 5050-5070. [CrossRef]

64. Saget, A.; Chebbo, G.; Bertrand-Krajewski, J.L. The first flush in sewer systems. Water Sci. Technol. 1996, 33, 101-108. [CrossRef]

65. Martinson, B.; Thomas, T. Quantifying the first-flush phenomenon: Effects of first-flush on water yield and quality. In Proceedings of the 14th International Rainwater Catchment Systems Conference, Kuala Lumpur, Malaysia, 3-6 August 2009.

66. Deletic, A.; Maksimovic, C.T. Evaluation of water quality factors in storm runoff from paved areas. J. Environ. Eng. 1998, 124, 869-879. [CrossRef]

67. Barco, J.; Papiri, S.; Stenstrom, M.K. First flush in a combined sewer system. Chemosphere 2008, 71, 827-833. [CrossRef]

68. Todeschini, S.; Manenti, S.; Creaco, E. Testing an innovative first flush identification methodology against field data from an Italian catchment. J. Environ. Manag. 2019, 246, 418-425. [CrossRef] [PubMed]

69. Gupta, K.; Saul, A.J. Specific relationships for the first flush load in combined sewer loads. Water Res. 1996, 30, 1244-1252. [CrossRef]

70. Zanandrea, F.; Silveira, A.L.L. Effects of LID Implementation on Hydrological Processes in an Urban Catchment under Consolidation in Brazil. J. Environ. Eng. 2018, 144, 04018072. [CrossRef]

71. Brito, L.K.S.; Costa, M.E.L.; Koide, S. Assessment of the Impact of Residential Urban Patterns of Different Hillslopes on Urban Drainage Systems and Ecosystem Services in the Federal District, Brazil. Sustainability 2020, 12, 5859. [CrossRef]

72. Fileni, F.; Costa, M.E.L.; Alves, C.M.A. The application of LIDs in Savanna region for mitigation of flooded areas. RBRH 2019, 24, e40. [CrossRef] 